\author{
Iwona Jażdżewska \\ https://orcid.org/0000-0002-4554-7486 \\ Uniwersytet Łódzki \\ Wydział Nauk Geograficznych \\ Instytut Geografii Miast, Turyzmu i Geoinformacji \\ iwona.jazdzewska@geo.uni.lodz.pl
}

\title{
URBAN NETWORK IN POLAND DURING LAST MILLENNIUM
}

\begin{abstract}
The article attempts to find in the history of Poland facts and processes that influenced the contemporary shape of the Polish urban network. In comparison with other parts of Europe, the process of urbanisation in Central and Eastern Europe was significantly delayed. During the last millennium, the Polish state changed its borders many times, mainly in the east-west direction, because the Baltic Sea from the north and the Sudeten and Carpathian ranges from the south effectively inhibited territorial changes in the north-south direction. The process of shaping and strengthening the urban settlement network in Poland to the present day has been divided into five periods. The first, lasting from the $8^{\text {th }}$ century until the union of Kreva in 1385, encompasses the beginnings of the establishment and spreading of urban settlement network; the second - the merger of the urban network with the Grand Duchy of Lithuania and its strengthening in the joint state; the third - the disappearance of Poland from the map of Europe and the breakup of the settlement network into three parts: tsarist Russia, the Habsburg monarchy, Prussia, and the start of industrialisation of the partitioned land; the fourth refers to the period when Poland, after 123 years, reappeared on the administrative map of Europe (1918-1939); and the fifth one covers the period from 1945 to the present day. When undertaking scientific research on the contemporary urban network of Poland, many political, social and economic factors should be taken into account. These should be taken into account when making hypotheses, drawing conclusions and developing economic and geographical theories.
\end{abstract}

Keywords: urban network, urbanization, historical and geographical perspective, Poland.

\section{MIEJSKA SIEĆ OSADNICZA W POLSCE W OSTATNIM TYSIĄCLECIU}

Abstrakt: W artykule podjęto próbę odnalezienia w historii Polski faktów i procesów, które wpłynęły na współczesny kształt polskiej sieci miejskiej. W porównaniu z innymi częściami Europy proces urbanizacji w Europie Środkowo-Wschodniej był znacznie opóźniony. W ciągu ostatniego tysiąclecia państwo polskie wielokrotnie zmieniało granice, głównie w kierunku wschód-zachód. Proces kształtowania się i wzmacniania miejskiej sieci osadniczej w Polsce do dnia dzisiejszego podzielono na pięć okresów. Pierwszy, trwający od VIII w. do unii w Krewie w 1385 r., obejmuje początki powstania i rozprzestrzeniania się miejskiej sieci osadniczej; drugi - połączenie sieci miejskiej z Wielkim Księstwem Litewskim i jej wzmocnienie we wspólnym państwie; trzeci - zniknięcie Polski z mapy Europy i rozpad sieci osadniczej na trzy części: carską Rosję, monarchię habsburską Prusy i początek industrializacji ziem zaborowych; czwarty odnosi się do okresu, kiedy Polska po 123 latach ponownie pojawiła się na administracyjnej mapie Europy (1918-1939); a piąty obejmuje okres od 1945 r. do współczesności. Na powojenną miejską sieć osadniczą duży wpływ miały procesy industrializacji, wynikające z planów partii komunistycznej dotyczących budowania podstaw socjalizmu w Polsce. Powstawały kolejne miasta (Nowa Huta, Nowe Tychy) i osiedla, z nowym urbanistycznym krajobrazem (osiedla blokowe). Rozwijano sieć komunikacyjną, ale tempo zmian nie było wysokie. Podejmując badania naukowe nad współczesną siecią miejską Polski, trzeba brać pod uwagę wiele czynników politycznych, społecznych i ekonomicznych. Należy to uwzględnić przy formułowaniu hipotez, wyciąganiu wniosków i opracowywaniu teorii ekonomicznych oraz geograficznych.

Słowa kluczowe: miejska sieć osadnicza; urbanizacja, perspektywa historyczno-geograficzna, Polska.

\section{INTRODUCTION}

The shape of the urban settlement network is undoubtedly a part of the cultural heritage of a country and depends on many factors, both natural, socio-economic and even political. The most important are the natural conditions of the geographical environment, determining the possibilities of settlement and development of an area, creating specific conditions for its permeability and political and territorial organisation, the layout of roads and trade routes, the population of the area and the degree of density of the rural settlement network associated with it, the level of economic development of the area and its contacts with neighbouring regions, 
the nature of the territorial organisation of political and administrative structures, and the location of their central centres, core areas and peripheries (Koter, Kulesza, 2001). The consequences of the processes that have taken place in the history of the settlement network are reflected in the contemporary structure of the urban network. This in turn may have an impact on the social and economic elements of the urban system (Kawashima, Korcelli, 1982; Moomaw, Shatter, 1996), as well as their spatial aspects, e.g. their polycentricity or reference to the theory of central (Hall, Pain, 2009; Wegener, 2013) cities. The changes in the landscape associated with the process of urbanisation in historical terms were indicated, among others, by (Antrop, 2004), who was wondering "How to assess the character or identity of a changing landscape and decide what is valuable for the future and might become traditional or heritage?" In turn, the reference to historical processes for individual cities and urban systems and their trajectories in the European and global urban system showed that three major styles are recognizable in their hierarchical and spatial organization dependent on several factors. Their properties vary according to their period of emergence (technological conditions during the urban transition determine spacefilling parameters) and according to any major exogenous impacts (such as colonization) (Bretagnolle, Pumain, 2010).

The notions of a city, urban network or system are a bit problematic, as they have changed over time (Frey, Zimmer, 2001; Guerin-Pace, Pumain, 1990), along with the administrative borders of states (Jażdżewska, 2006).

The article attempts to find in the history of Poland facts and processes that influenced the contemporary shape of the Polish urban network. Indicating them may indirectly contribute to a better understanding a lot of aspects occurring in Polish cities. The process of shaping and strengthening the urban settlement network in Poland is discussed in several stages directly related to the history of this country. The analysis was based on the research of historians and geographers. Historical maps and statistical sources were also used. Finally, the processes that took place in the urban network in the last century and the factors that may have had the greatest influence on its current shape were indicated.

\section{HISTORICAL AND GEOGRAPHICAL PERSPECTIVE}

Cities on Polish territory have been established and developed for over 1000 years. However, in comparison with other parts of Europe, such as Western and especially Southern Europe, the process of urbanisation in Central and Eastern Europe was significantly delayed (Krzysztofik, 2007; Krzysztofik, Szmytkie, 2005). Above all, there was no urbanisation in the ancient period on Polish territory, as this part of the European continent was not covered by either Greek civilisation or the Roman Empire (Antrop, 2004). Therefore, apart from rare Roman finds in the form of coins, fragments of armaments, and products of material culture, there are no remains of ancient cities, so clearly visible in the settlement network of contemporary Greece, Italy, Spain, Portugal, Germany, Croatia or France.

During the last millennium, the Polish state changed its borders many times, mainly in the east-west direction, because the Baltic Sea from the north and the Sudeten and Carpathian ranges from the south effectively inhibited territorial changes in the northsouth direction (Fig. 1). Poland is a country with the largest territorial variation in the history of Europe (Kulesza, Kunka, 1994). These changes involved not only the temporary gaining and losing some provinces that were later regained, but a transition of the country from its natural geographical frames deep into neighbouring ecumenes, while losing its own historical borders in the process. There were also times when the Polish state would disappear from the map of Europe for extended periods (Koter, Kulesza, 2001). Each change of these boundaries entailed a transformation in a settlement network, both its structure and the area it covered (Tab. 1). The development of the urban settlement network in Poland was therefore largely conditioned by the political situation and its consequences.

Table 1. Changes in the size of the Polish territory in the $10^{\text {th }}-20^{\text {th }}$ century

\begin{tabular}{|l|c|c|c|}
\hline Years & $\begin{array}{c}\text { Surface area } \\
\text { in thousand } \mathrm{km}^{2}\end{array}$ & Years & $\begin{array}{c}\text { Surface area } \\
\text { in thousand } \mathrm{km}^{2}\end{array}$ \\
\hline 990 & 250 & 1580 & 865 \\
\hline 1018 & 380 & 1634 & 990 \\
\hline 1300 & 200 & 1771 & 733 \\
\hline 1370 & 240 & 1922 & 389 \\
\hline 1466 & 260 & 1951 & 313 \\
\hline
\end{tabular}

Source: Koter, Kulesza (2001).

The process of shaping and strengthening the urban settlement network in Poland to the present day has been divided into five periods. The first, lasting from the $8^{\text {th }}$ century until the union of Kreva in 1385, encompasses the beginnings of the establishment and spreading of urban settlement network; the second - the merger of the urban network with the Grand Duchy of Lithuania and its strengthening in the joint state; the third - the disappearance of Poland from the map of Europe and the breakup of the settlement network into three parts: tsarist Russia, the Habsburg monarchy, Prussia, and the start of industrialisation of the partitioned land; the 


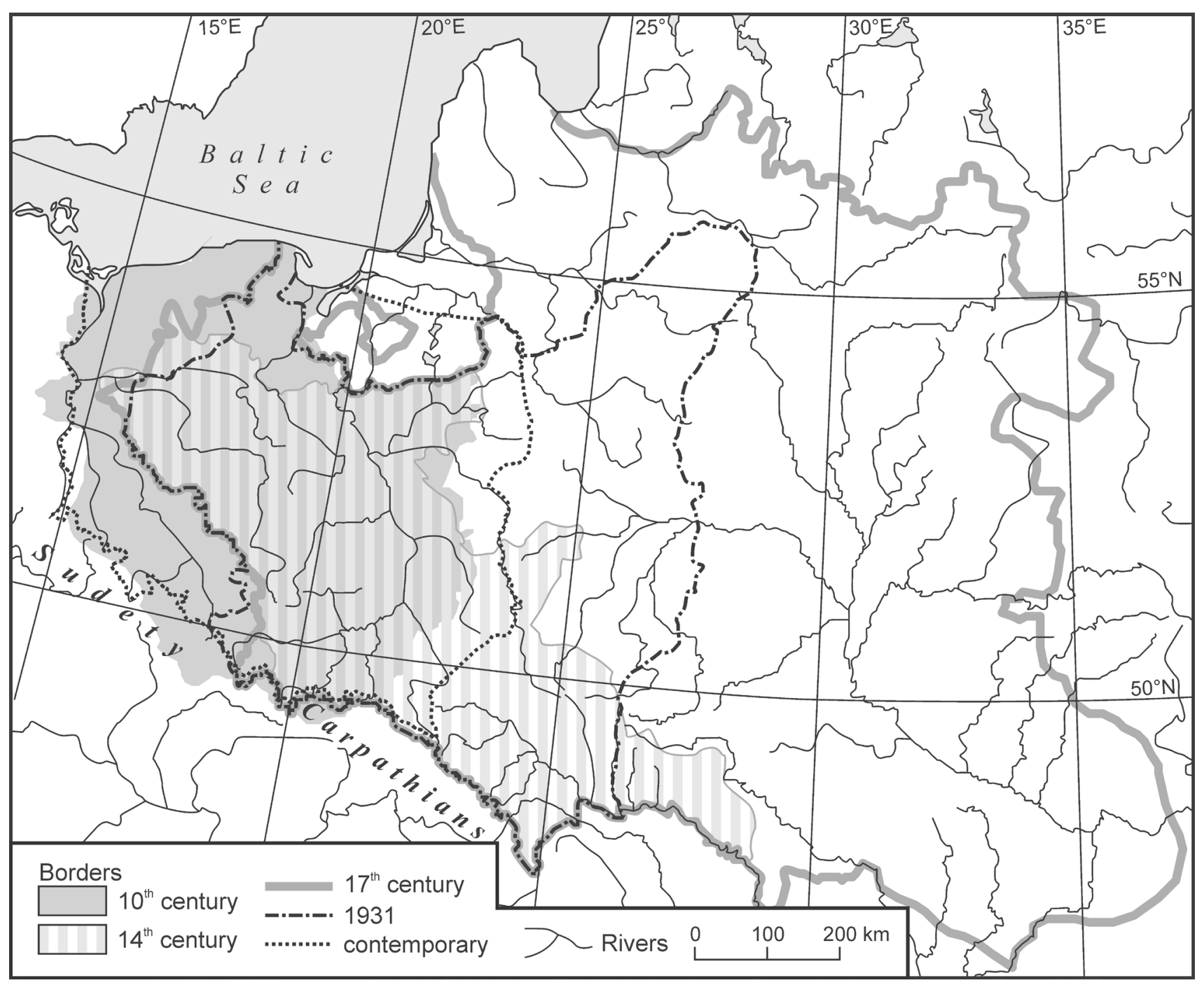

Figure 1. Administrative changes in the borders of Poland from the $10^{\text {th }}$ to the $20^{\text {th }}$ century Source: Jażdżewska (2008, p. 33)

fourth refers to the period when Poland, after 123 years, reappeared on the administrative map of Europe (19181939); and the fifth one covers the period from 1945 to the present day.

\section{FIRST STAGE \\ ESTABLISHMENT AND SPREADING OF AN URBAN SETTLEMENT NETWORK IN POLAND}

In the $10^{\text {th }}$ century, new states were created on the European political scene, in chronological order: Bohemia replaced by Hungary, Ruthenia, Norway, Czechia, Denmark, Poland and Sweden. The emergence of all these new organisms was based on the inflow of means which made possible the formation of elites interested in building new social organisations (Samsonowicz, 2010). The history of cities in Poland and the formation of an urban settlement network goes back more than ten centuries (Jażdżewski, 1957). During this period, more than 1400 complexes and settlement units were established, which in the past or now have the status of a city. They have survived in various states: from negligible archaeological relics to completely preserved complexes with old layouts and often intact building tissue (Kalinowski, 1986).

The first cities in Poland were distinguished in terms of economy and politics: Gniezno, Poznań and Kruszwica (the basin of the Warta and Noteć rivers, the right-bank tributaries of the Oder River), Wolin and Szczecin (the mouth of the Oder River), Kraków, Wiślica and Opole (the upper Vistula and Oder). An important element in the process of creating cities was the legal act (the incorporation charter), which granted town privileges to the settlements. It was not related 


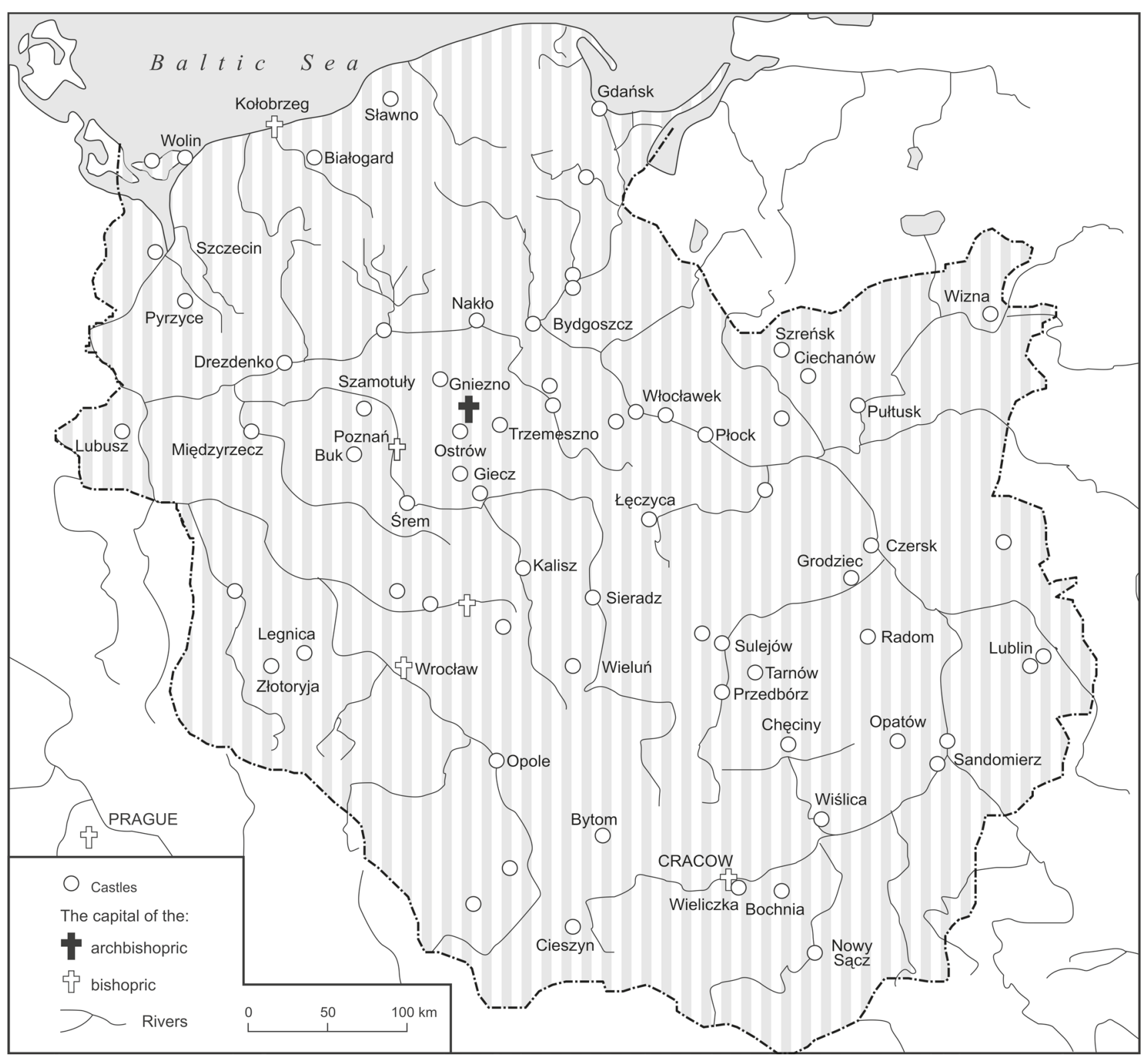

Figure 2. Urban settlement network during the reign of Bolesław Chrobry $10^{\text {th }}-11^{\text {th }}$ centuries Source: Jażdżewska (2008, p. 36)

to the size and functions of the settlement, but to its economic reconstruction programme (Samsonowicz, 1980). The first incorporation in Poland took place in 1211 in Złotoryja, Silesia, which in this process overtook the other historical districts by about $10-40$ years (Fig. 2).

During the reign of the Piast dynasty in Poland (10 $10^{\text {th }}-14^{\text {th }}$ centuries), the shape of the urban settlement network was largely determined by the policies, including foreign policy, of the rulers. It was owing to the efforts of Bolesław Chrobry that the archbishopric in Gniezno (still absent in Czechia which had not yet adopted Christianity by that time) and four bishoprics - in Kraków, Poznań, Wrocław and Kołobrzeg - were located in Poland in 1000 (Fig. 2). Cities which had an additional metropolitan function in the Roman Catholic
Church were important links not only in the network of Polish but also European cities. In the first half of the $13^{\text {th }}$ century the rulers of Poland brought in the Teutonic Knights, who in less than 200 years founded many cities, including1: Chełmno (Kulm), Toruń (Thorn), Kwidzyn (Quedin), Bytów (Bütow), Malbork (Marienburch), Braniewo (Braunsberg), as well as Kaliningrad (Königsberg), Klaipeda (Memel), building castles and fortifications in them and establishing their own Kulm law for them (Czaja, 2000; Musiaka, 2015).

Wars, treaties and peace pacts, "survival" agreements and often marriage were among the most important instruments of foreign policy. Owing, among others, to the latter, the Piast dynasty, the first dynasty to reign in Poland, was in conflict with the most prominent European families both on the eastern and western 
side of their country. This also brought them tangible territorial benefits. After the death of the last Rurik (1340), Casimir the Great annexed to Poland the Halychian Ruthenia, and took in fief Podolia, the Duchy of Vladimir and the Principalities of Belz and Chełm. At that time, Poland's urban settlement network stretched southeast and occupied part of the Dniester and Pripyat basins. The most important elements of the new part of the network were the oldest castles: Halicz (the capital of the duchy and the Orthodox metropolis, located on an important trade route from Kiev to Regensburg), Włodzimierz (the capital of the duchy and the Orthodox bishopric), as well as Lviv, Kamianets-Podilskyi, Kremenets, Chełm and Belz, where the construction of fortifications and urban reform began (Fig. 3). Owing to the political decisions of the king, which changed the territory of the country, the urban settlement network of Poland in the southeast was connected with a new part of the urban network. At that time it spread across the Vistula river basin (the Baltic Sea catchment area) and parts of the Dniester and Pripyat basins (the Black Sea catchment area).
Not all political decisions taken by the Piasts led to the territorial growth of Poland. As a result of the Cracow Treaty of 1366, the aforementioned king Casimir the Great gave up the fief and de facto gave Silesia to Czechs As a result, Poland's urban settlement network was deprived of many old and rich cities, such as Głogów, Wrocław, Opole, Bytom, Świdnica and Legnica, located in the Oder River basin (compare Fig. 1 and 3). The other agreement of this ruler with the Hungarian Angevins, in the absence of a male descendant, gave the throne to one or the other contracting party. From 1370 the Piasts' successors on the Polish throne were Louis of Hungary, succeeded by his daughter Hedwig. The future showed how important it was and how it influenced the later shape of the country's territory. The complicated history of late medieval Poland, wars, unsuccessful treaties and carelessness of the rulers caused the loss not only of Silesia, but also of Pomerania, where some of the oldest cities, probably of strategic importance in the settlement network, were located This involved Kolobrzeg, Wolin, Szczecin, Slupsk and Gdansk, located on the Baltic Sea.

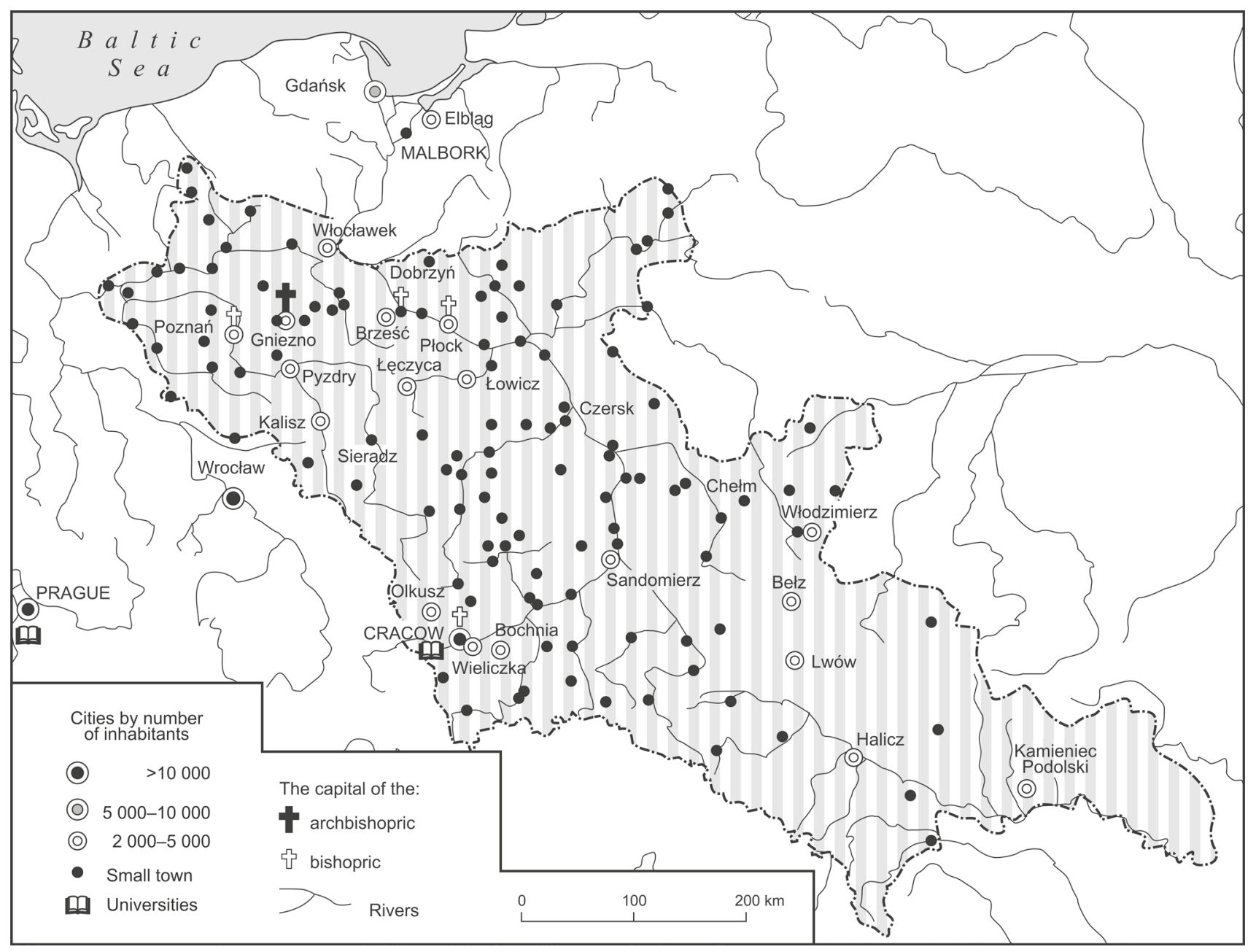

Figure 3. Urban settlement network during the reign of Casimir the Great in the $14^{\text {th }}$ century Source: Jażdżewska (2008, p. 37) 
An important decision taken by Casimir the Great was the founding in 1364 of the first university in Cracow, which developed dynamically in the following years under the rule of the Jagiellonian dynasty. The Jagiellonian University has been operating without interruption and has always been one of the most renowned universities in Europe. Many excellent scholars studied here, including Nicolaus Copernicus (since 1491) (History of the Jagiellonian University, 2019).

\section{SECOND STAGE. STRENGTHENING THE URBAN SETTLEMENT NETWORK}

The taking of the Polish throne by the Lithuanian Jagiellons was a decisive event, which had a significant impact on the shape of the country's territory and, consequently, on the development of the settlement network. Thanks to the agreement between Poland and the Grand Duchy of Lithuania, concluded in 1385 in Kreva, Queen Hedwig of Poland married Władysław Jagiełło, the ruler of Lithuania. This marriage, undoubtedly a political decision, caused Poland to associate itself for several hundred years with the Grand Duchy of Lithuania, avoiding any rapprochement with the Austrian Habsburgs, whose state bordered Poland from the south-western side. The territory of indigenous Lithuania was occupied mainly by the Neman basin, but the area of this Principality reached far south-east to the Dniester River. The largest cities of the added Lithuanian settlement network were: Vilnius (the capital of the Grand Duchy of Lithuania), Trakai, Novgorodek, Minsk, Brest of Lithuania, as well as Kiev (since 1363), Polotsk (since 1375) and Smolensk (since 1404), which expanded and enriched the urban settlement network built in the Piast era.

Jagiellonian foreign policy was dominated by competition with the Teutonic Order, and later with the Moscow State, and aimed at reinforcing its power

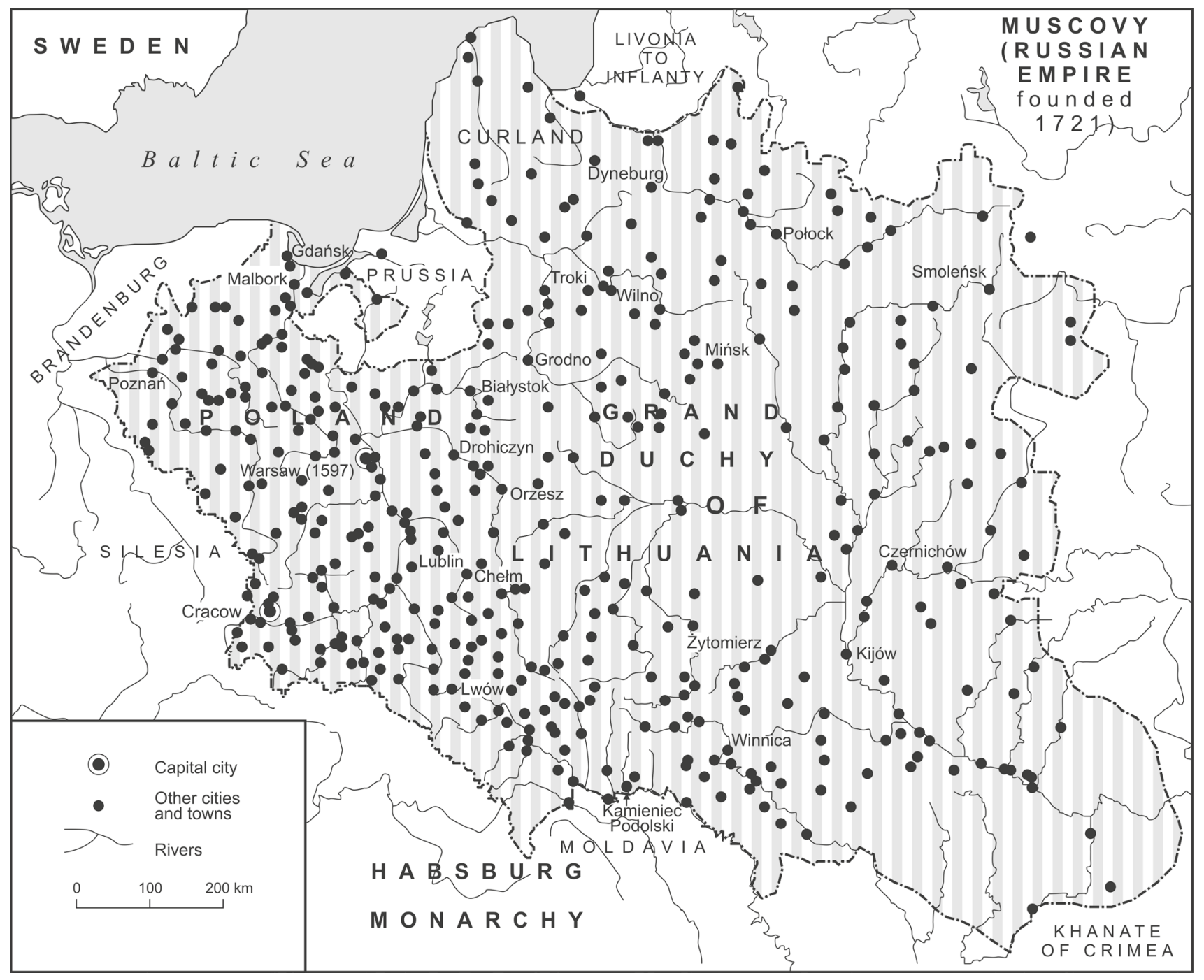

Figure 4. Urban settlement network during the reign of the Jagiellonian dynasty in $14^{\text {th }}-15^{\text {th }}$ centuries Source: Jażdżewska (2008, p. 40) 
over the newly conquered areas in the Dnieper and Dniester river basins. After the victorious war with the Teutonic Knights (in 1466) and then the secularisation of the Teutonic Knights, Prussia was formed as a fief of the Polish Crown. Shortly afterwards, the Jagiellons, using the secularisation of the next Order - the Livonian Brothers of the Sword, briefly subjugated Courland, Semigalia and Livonia in the area of the Gulf of Riga. They were more successful in the southeast, where they occupied Podolia and Ukraine up to the liman of the Dnieper (Fig. 4). Unlike the former territories of the orders, where there was a network of solid Gothic cities, the Eastern Borderlands, commonly known as "wild fields", were sparsely populated and poorly urbanised.

The changes in the urban settlement network that took place during the Jagiellonian period can be described as quantitative and cultural. The cities of Pomerania and Prussia, mostly inhabited by the German bourgeoisie, were incorporated into the urban settlement network established in Poland before the $15^{\text {th }}$ century. The annexed cities and castles of the Grand Duchy of Lithuania were established under the influence of Russian, Lithuanian and Polish colonisation, and their Russian organisation was gradually changed on the basis of Magdeburg law. Polish, Lithuanian, German, Jewish, Armenian and Russian settlers and merchants travelled to the towns located on the eastern borderlands of the Republic of Poland, giving them a picturesque multinational character, often reflected in the morphology of these towns ${ }^{2}$. The number of cities in particular regions of the Polish state varied at that time (Fig. 4). In the $16^{\text {th }}$ and $17^{\text {th }}$ centuries, the process of urban development was halted, with some cities even collapsing. It was caused by demographic factors and the feudal system, as the peasants could not leave the manor to which they were assigned and consequently the rural population ceased to flow into the towns. In addition to internal factors such as epidemics, wars, fires and devastating serfdom, there are also events on a European scale that have had a decisive impact on urban development. The first one is the decimation of the population of Western Europe by the plague, and the second is the discovery of America and the change of direction of migration from east to west. The cities of Central and Eastern Europe were no longer as economically attractive as newly discovered continents (Dziewoński, 1947).

\section{STAGE THREE. THE RUPTURE OF THE POLISH SETTLEMENT NETWORK THE BEGINNINGS OF INDUSTRIALISATION}

From the end of the $17^{\text {th }}$ century, the changes in the territory of Poland were mostly determined by the foreign policy of the neighbouring countries, and not by the
Polish rulers, which was reflected in the collapse of the Polish state at the end of the $18^{\text {th }}$ century and its disappearance from the map of Europe as a result of the subsequent partitions carried out by the tsarist Russia (62\% of the area), Prussia (20\%) and the Habsburg Monarchy $(18 \%)$. As a result, the existing urban settlement network was cut by three national borders for 123 years. This had serious consequences. The invaders were not interested in strengthening and developing cities in their borderlands, they often led to the stripping of their city rights. One example is the Tsarist decree of 1869, which eliminated the legal basis of 338 cities under Russian rule. According to (Jelonek, 1967), at the beginning of the $19^{\text {th }}$ century, the urban network in the Russian partition was a sign of the final phase of the feudal development of the urban network in the Polish lands. Partitions caused Polish cities at the outskirts of the partitioning countries to develop in completely different conditions, which made them economically impaired. Only the process of industrialisation, which took place in each of the partitions, began the period of economic growth of the existing cities and the appearance of new ones.

After the creation in 1815 of Congress Poland as part of the Russian Empire, urban issues were some of the most important aspects for its autonomous government. This was important, as there were 451 cities with $19.5 \%$ of the country's population living in the area of 128.5 thousand square kilometres. More than ten years later, in 1827 this number increased to $21.5 \%$ and in 1861 it already constituted $24.2 \%$ of the total population of the country (Grabowski, 1914).

This was a result of the industrialisation of cities and the abolition of serfdom by Tsar Alexander II in 1861. Industrialisation allowed some of them to survive and some, such as the agricultural Łódź, to develop rapidly. The development of Łódź was so fast that it can be compared only with the development of American cities (Grabowski, 1914). Łódź changed the historically shaped settlement network in this region of the country (Jażdżewska, 2001). In the vicinity of Łódź, where the production of cotton and linen fabrics dominated, towns and textile settlements developed. The number of inhabitants of Łódź and the surrounding towns in 1913 was about 800,000. A competitive textile industry centre appeared in the north-eastern part of the Kingdom, where the first magnate and bourgeois factories were established in the vicinity of Bialystok. The mining, metallurgical and metal industries were located in several places in: Warsaw, in the Old Polish Industrial District and in the Dąbrowa Basin. In Sosnowiec, located in the Dąbrowa Basin, there was a similar phenomenon of a rapid increase in the number of inhabitants as in Łódź. Apart from Sosnowiec, Będzin, Dąbrowa Górnicza, Czeladź and the surrounding communes 
developed, creating a population of over 300 thousand inhabitants (Grabowski, 1914).

A characteristic feature of the urbanisation processes of this period of industrialisation was the deepening regional differentiation. The economic recovery led to the creation of leading centres in livestock and agricultural production, trade and industry. The development of land transport, both road and rail, contributed significantly to this. The opening of the St. Petersburg - Warsaw - Vienna railway line in the $19^{\text {th }}$ century, with a branch to Łódź, and Warsaw - Bydgoszcz, opened up great prospects for development of the cities located in the vicinity of these routes. These factors significantly exacerbated the differences in the pace and nature of urbanisation. The most economically advanced southwestern regions of the Kingdom of Poland consolidated their advantage over the north-eastern voivodships at that time (Koter, Kulesza, 1997). At the beginning of the $20^{\text {th }}$ century, the level of urbanisation in Congress Poland was not evenly distributed - it was close to $30 \%$ in the south-western part, while on the northeastern side it exceeded $10 \%$.

The territory of the Russian partition included, apart from the Kingdom of Poland, Ruthenia ${ }^{3}$, Lithuania and Belarus. Only four Russian cities (Berdychiv, Zhytomyr, Bila Tserkva and Vinnitsa) had more than 50000 inhabitants, but did not reach 100 000, and in Lithuania and Belarus four cities (Minsk, Daugavpils, Vitebsk, Gomel) had more than 100000 inhabitants, and one city (Vilnius) had more than 200000 inhabitants.

In the Prussian partition, the process of urbanisation was faster, as serfdom had been abolished several dozen years earlier than in Russia. However, small towns of typical agricultural character dominated, with only Poznań and Gdańsk exceeding 100 thousand inhabitants. The exception was Silesia, where from the beginning of the $19^{\text {th }}$ century a large centre of heavy industry was created on the basis of hard coal in its eastern part, in the so-called Upper Silesia. A dozen or so of them created a conurbation, among them: Katowice (Kattowitz) (Murzyn-Kupisz, Gwosdz, 2011), Gliwice (Gleiwitz), Bytom (Beuthen), Zabrze (since 1915 Hindenburg), Chorzów (Königshütte), Tarnowskie Góry (Tarnowitz), Racibórz (Ratibor). The development of towns was strongly influenced by the railway network established in the $19^{\text {th }}$ century, connecting large industrial towns with smaller agricultural settlements. It was the densest railway network in the three partitions and the first one to be electrified (1915). Both agricultural crops and hard coal were transported to Wrocław, Szczecin, Berlin and Gdańsk (Lijewski, 1977).

In the Austrian partition of the Habsburg Monarchy, in the area called Galicia, in 1817 there were almost 300 towns, most of them small. Their economic condition was very low. Serfdom was abolished in 1848, but the pace of urbanisation processes was extremely slow and did not correspond to the rapid growth of the population in rural areas. Two large cities, Lviv (207 000) and Cracow (154 000), stood out in the vast territory of Galicia. The weaving and mining industries played an important role in the development of some cities (Jelonek, 1967). There are salt deposits in this area, owing to which Bochnia and Wieliczka developed. The Carpathians, on the other hand, had oil deposits, which began to be extracted near Krosno, Jasło and Gorlice, as well as Drohobycz and Borystów. At that time, a network of railway connections was also built, including: Lviv - Cracow - Vienna, Cracow with the cities of Upper Silesia (Lijewski, 1977).

The territory occupied by the invaders was diverse in terms of the number of cities and their structure. The highest percentage of urban population in the years 1910-1913 was to be found in: Opole Region (which included the industrial cities of Silesia), where $41.3 \%$ of the urban population lived, the Kingdom of Poland $(31.5 \%)$, Prussia $(26.6 \%)$ and the Grand Duchy of Poznan (24.4\%). In the remaining districts, the urban population constituted less than $20 \%$ of the total, with the lowest share in Lithuania, Belarus (11.86\%) and Ruthenia (10.42\%) (Krzyżanowski, Kumaniecki, 1915).

The influence of new railway lines built in the years 1860-1910 on the development of cities was not equal and depended on many factors, e.g. on the type of connection between the city and the railway line, as well as on the size of the city. The existence of node stations in the city was a stimulating factor, clearly building the city, while the impact of intermediate or terminal stations was rather small. In the case of small urban settlements, the establishment of a railway node as generally been a driver for further growth (Krzymowska-Kostrowicka, 1972). It also depended on the partition, in Prussia the railway lines were connected with the settlement network to serve the travellers, while in the Russian Empire they were distant from the settlement network because they served military (Lijewski, 1977) purposes.

Until the end of the First World War (1918), one cannot speak of a sovereign Polish state. It was not until the Treaty of Versailles that Poland was established within its own borders independent of foreign powers. Within a few years (1920-1921) wars or armed uprisings were waged: against Ukraine for Lviv, Lithuania for Vilnius, Czechoslovakia for Cieszyn, Germany for Silesian cities (three uprisings and plebiscites, as a result of which its eastern part was incorporated into Poland), including Katowice and Chorzów, as well as for Poznań (an uprising in Wielkopolska). The longest war, which threatened independence, lasted from 1919 to 1920 with Bolshevik Russia. It was not until the treaty signed in Riga in 1921 that the border in the east was finally drawn. 


\section{FOURTH STAGE. THE INTERWAR PERIOD}

In 1936, the urban settlement network consisted of 636 towns (Fig. 5). The urban network encompassed the basins of: Oder, Vistula and Neman - the catchment area of the Baltic Sea, and Dniester, Prypiat - the catchment area of the Black Sea. The Treaty of Versailles also defined the northern borders, as a result of which Poland gained access to the Baltic Sea, but the city of Gdansk, the most important port on this section of the coast, became a Free City, although practically within the German sphere of influence. For this reason, it was decided as early as in 1920 to create a port city of Gdynia, which was established to the north of the Free City of Gdańsk. Before 1939, 75\% of cities in Poland were small, up to 10000 inhabitants, while almost $50 \%$ were very small - up to 5000 inhabitants.

From the point of view of city density and urban population share, several regions can be distinguished in this period (Fig. 5). One of them was Wielkopolska, located in the west, with one large city, Poznań, and a large density of very small towns. The second was

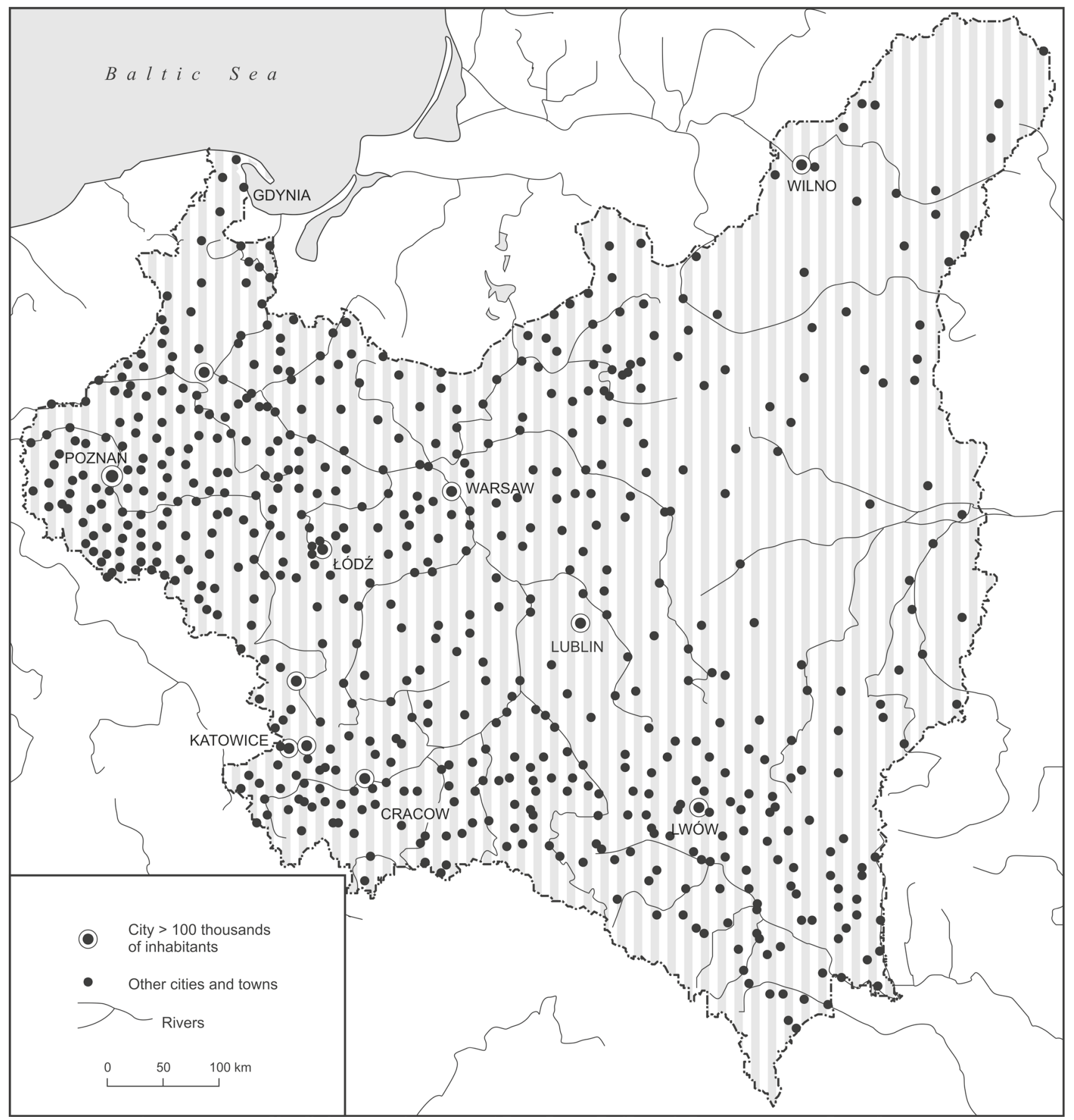

Figure 5. Urban settlement network in 1931 Source: Jażdżewska (2008, p. 59) 
southern Poland with a distinctive concentration of industrial cities of Silesia with the largest city of Katowice, a fairly dense urban network arranged along the arch of the Carpathians with large cities of Lviv and Krakow. The third are the cities located in the centre, in which the two largest cities in Poland at that time, Warsaw and the industrial city of Łódź, stand out. There were many towns around them but their density is lower than in the first two regions mentioned above. The fourth region with the largest surface area and the lowest share of cities is located in the north-eastern part of Poland. There were mostly small towns there, and among them only Vilnius had more than 100000 inhabitants. The last region with the smallest area can be found in the north. It consisted of the port city of Gdynia and a network of towns lying along the mouth of the Vistula River (but excluding Gdańsk).

From an economic point of view, the "young" state was to create a legal basis, a new currency and to connect, in terms of communication, administration and economy, the areas which functioned in three state structures (Wolf, 2005). "Poland was without hands-on knowledge of basic modern economic institutions in 1918" (Hartwell, 2018). In such a short period of time (1918-1939) a lot of work was done. The Polish industrial sector has adapted in a surprisingly similar way to the dynamics of the contemporary European Union (Wolf, 2007) but monetary policy has notbeen properly conducted and hyperinflation has affected many aspects of life (Hartwell, 2018). Along with other Eastern European countries, Poland was then classified as a third world country, i.e. countries that had about half or more of the population dependent on agriculture, and the income per capita was less than 50 per cent of the developed countries of Western Europe (Aldcroft, 2006).

The consequences of the Second World War, the Nazi and Soviet occupation caused enormous losses among the population. Several dozen percent of their citizens have not returned to Polish cities. The death of the Polish and Jewish population, as well as the displacement of the German population from independent Poland, deprived the cities and towns of a specific multinational atmosphere. The loss of population in cities often exceeded $50 \%$ and was not evenly distributed throughout the country. It was larger the further east it went.

\section{FIFTH STAGE CONTEMPORARY URBAN NETWORK AND ITS CHARACTERISTICS}

After 1945, within the new borders set by the victorious leaders in Yalta, Poland found itself under the influence of the Soviet Union and the new communist political and economic system (Fig. 6). As a result of the Yalta agreements, the territory of Germany with its settlement network was joined with Poland, while the eastern part was removed from it. Poland lost almost half of its territory to the USSR and its eastern border was moved $300 \mathrm{~km}$ to the west, with the Bug River becoming the border line. The western border of Poland was also moved to the west, and the Oder and Lusatian Neisse rivers became the border (Fig. 1 and 6). Together with the territory incortporated into the USSR, more than 160 towns were cut from the urban settlement network, while about 250 post-German towns were attached. The urban network included the basins of two rivers Oder and Vistula, which makes it comparable to the one at the beginning of the Polish state (Fig. 2). The Germans were forced to leave their homes and resettled to the territories on the other side of the Oder River. Poles in the east, who had to leave their family homes, suffered a similar fate. A significant number of displaced Poles found themselves in the post-German territories then called the Recovered Territories.

The post-war urban settlement network was strongly influenced by industrialisation processes that resulted from plans developed by the communist party to build the foundations of socialism in Poland. The first investment plans developed in the 1950s mostly concerned heavy industry and armaments related to the creation of an industrial and military complex of the Warsaw Pact countries. Construction started on 80 new industrial plants (including coal mines, power plants, steelworks, chemical plants, cement plants and machinery industry). In the nineteen-seventies alone, there was an increase in investment in the consumer industry, and the largest investments were made in furniture, car and clothing plants. Heavy industry was still developing, and steel mills, mines, cement plants, refineries and others were built. Apart from the mining industry, the locations of new industrial investments were chosen by the party, not guided by the economic context of the location, but by its internal policy.

It is worth noting that for the first time in history, as a result of the new political and economic system, serious ownership changes took place: the nationalisation of land and real estate, as well as the adoption of legal and architectural solutions from the East. New cities (Nowa Huta, Nowe Tychy) and housing estates were created, with the urban ladscape turning into blocks of flats. The communication network was being developed but the pace of change was not high.

The centrally planned economy led to several serious social crises $(1956,1970,1980)$ and political and economic changes in 1989. Before the reform, the Polish economy was defined by hyperinflation, macroeconomic crisis, foreign debt, dependence of the economy on the USSR, economic centralisation and the particularly strong socio-political position of the labour movement (Balcerowicz, 1994). 


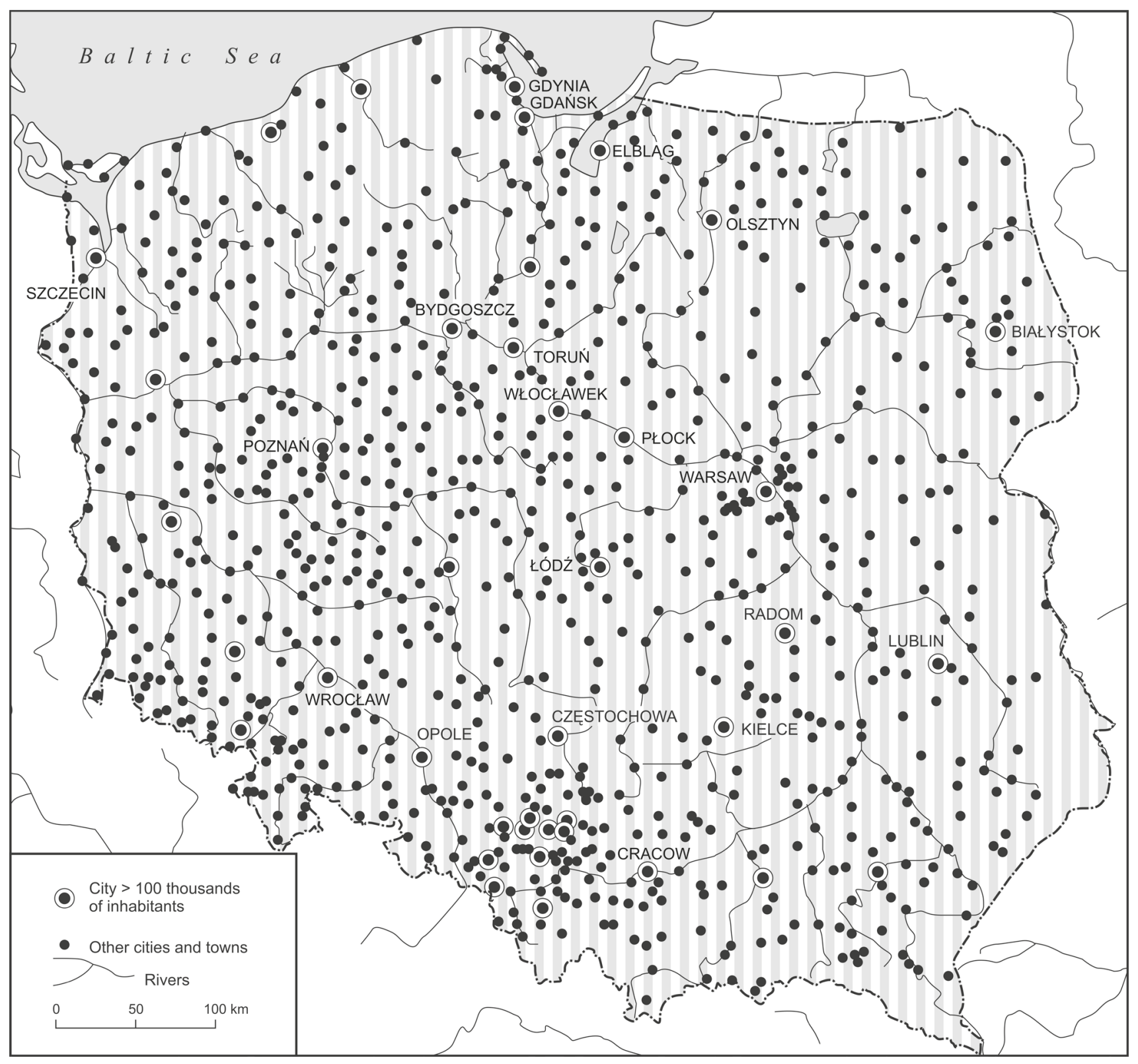

Figure 6. Urban settlement network in 2002 Source: own study

The transition from a centrally planned economy to a free market economy and the implementation of the "Balcerowicz Plan" was not without difficulty but was successful. Owing to the legal and economic reform, the private sector developed in Poland, the Polish currency became convertible, foreign investment increased, labour productivity increased. The need to adapt to the requirements of the European Union and Poland's accession to the EU (as well as NATO) resulted, among others, in an increase in the sense of security, elimination of border barriers, increase in foreign capital and further development of the communication network, which makes cities more accessible for business entities and improves their development.
Among the social factors influencing the contemporary shape of the Polish urban network after World War II, several factors should be mentioned: high birth rate in the post-war years, labour orders, bans on registering in several cities and internal migrations. During the $20^{\text {th }}$ century, they went through several stages. The first post-war direction of migration took place mainly from rural areas to cities (Rykiel, Jażdżewska, 2002). After 2000, this direction was revrsed, with more people migrating to rural areas, especially the suburban ones (Fig. 7). Both cities and their functional areas have changed their number of inhabitants in recent years, but the pace of change has been different (Śleszyński, 2013), as was the direction of migration (Długosz, 2006). 


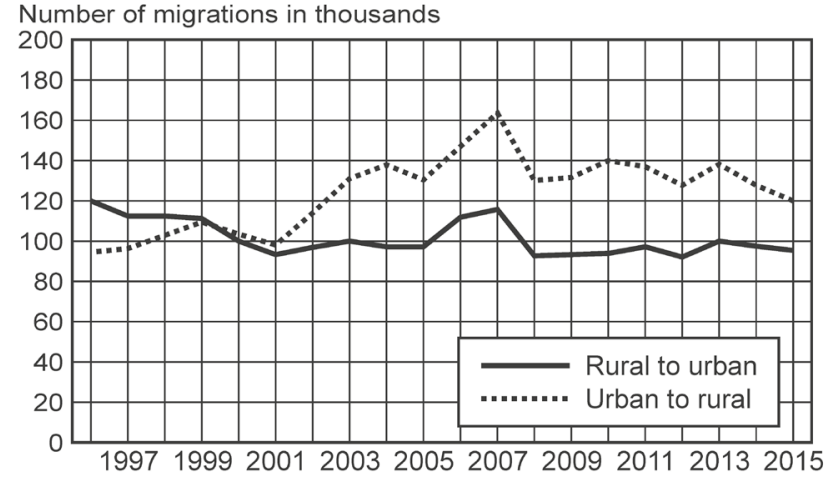

Figure 7. Migration between urban and rural areas in Poland in the years 1996-2015 Source: own study

Poland was dominated by small and even very small towns (Fig. 8). Towns with less than 10000 inhabitants have always constituted more than $50 \%$ of all towns. They have struggled with many demographic and economic problems (Zuzańska-Zyśko, 2003; KwiatekSołtys, 2011). Their share was biggest in the post-war years, as a consequence of population losses. Then it decreased, to start growing again at the beginning of the $21^{\text {st }}$ century, which is a consequence of the increase in the number of small towns and a decrease in the number of inhabitants in mid-sized towns and cities.

The number of largest cities (>500 000) has increased over the century from one to five: Warsaw (1.8 million), Kraków (0.8 million), Łódź (0.7 million), Wrocław (0.6 mil-

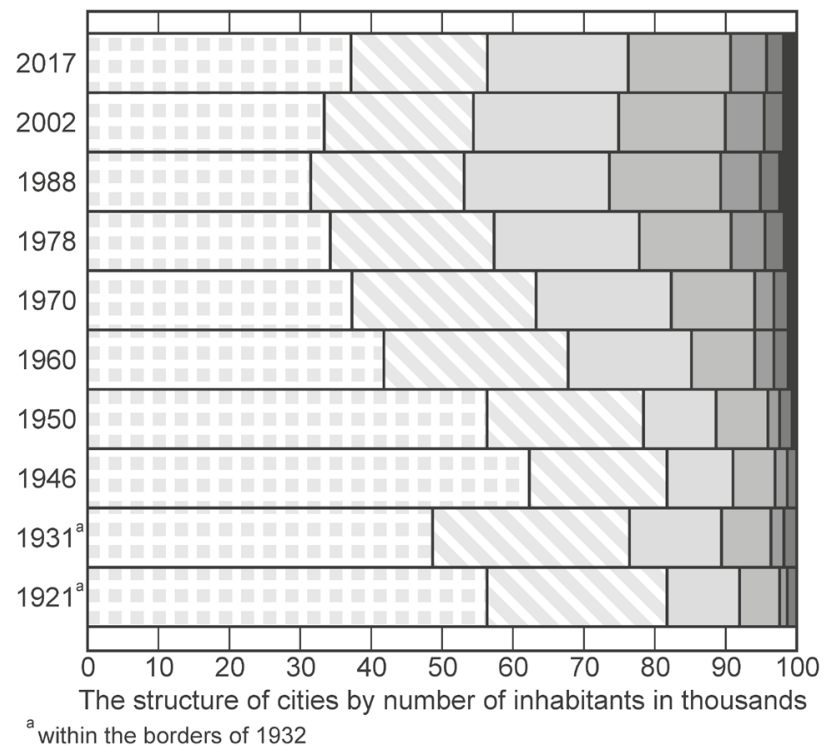

Figure 8. Structure of cities in Poland in the years 1921-2017 by their number of inhabitants

Source: own study based on The Central Statistical Office data

lion) and Poznan (0.5 million). The rank of most of the ten largest cities has changed over a period of nearly 100 years (Fig. 9). Several aspects are worth noting. Between 1931 and 1950 - as a result of changes in the administrative borders of Poland, to biggest cities, Lviv and Vilnius disappeared from the group of the largest cities, but five former German ones joined it: Wrocław, Gdańsk, Szczecin, Bytom and Zabrze. In the second half

\begin{tabular}{|c|c|c|c|c|c|c|c|}
\hline Rank & 1931 & 1950 & 1960 & 1978 & 1988 & 2002 & 2017 \\
\hline 1. & Warsaw & Warsaw & Warsaw & Warsaw & Warsaw & Warsaw & Warsaw \\
\hline 2. & Łódź & Łódź & Łódź & Łódź & Łódź & Łódź & Kraków \\
\hline 3. & Lviv & Kraków & Kraków & Kraków & Kraków & Kraków & Łódź \\
\hline 4. & Poznań & Poznań & Wrockaw & Wrocław & Wrockaw & Wroclaw & Wrockaw \\
\hline 5. & Kraków & Wroclaw & Poznań & Poznań & Poznań & Poznań & Poznań \\
\hline 6. & Vilnius & Gdańsk & Gdańsk & Gdańsk & Gdańsk & Gdańsk & Gdańsk \\
\hline 7. & Katowice & Szczecin & Katowice & Szczecin & Szczecin & Szczecin & Szczecin \\
\hline 8. & Czestochowa & Katowice & Szczecin & Katowice & Bydgoszcz & Bydgoszcz & Bydgoszcz \\
\hline 9. & Bydgoszcz & Bytom & Bydgoszcz & Bydgoszcz & Katowice & Lublin & Lublin \\
\hline 10. & Lublin & Zabrze & Zabrze & Lublin & Lublin & Katowice & Białystok \\
\hline
\end{tabular}

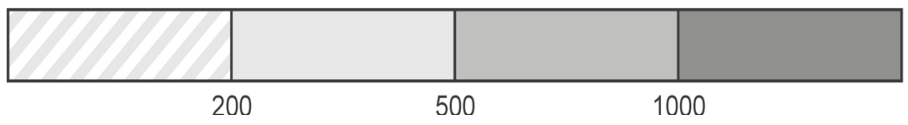

Figure 9. Changes in the order of the 10 largest cities in Poland in the years 1931-2017 by population Source: own study based on The Central Statistical Office data 
of the $20^{\text {th }}$ century there was a decrease in the number of cities with 100-200 thousand inhabitants and a growing number of larger cities. The industrial cities of Silesia (Katowice, Bytom, Zabrze) and recently Łódź have lost their rank, and the cities of eastern Poland, Lublin and Białystok, have gained it.

\section{DISCUSSION AND CONCLUSIONS}

Referring to the history of Poland and its urban network, it can be said that it is in a constant "movement" both in terms of space occupied and socio-economic situation. Cities that served or still serve as capitals (Kraków and Warsaw since 1596) have always had a very good position in the urban network. Despite the fact that it gave up its administrative function, Kraków was still important in the administrative network of the Catholic Church and as one of the oldest universities in Europe. These two cities belong to the group of few large cities that have experienced population growth within their administrative boundaries. Three out of five cities in the group of high importance are those in which bishoprics were established in 1000 (Cracow, Poznań and Wrocław). For several hundred years, Wrocław was outside the borders of the Polish state and was one of the most important cities in Silesia. It reputation may be proven by the Leopold University, founded in 1702 by the Jesuits, with its heir in the University of Wrocław. Among its graduates are several Nobel Prize winners, who studied here when it was a German university. The city continues to develop and attract new residents. For centuries, Poznań has been the capital of the historical region of Wielkopolska, where most of the towns are small and do not threaten its position in the urban network. It is also an academic city, but in recent years it has been losing its population to small towns and villages in its vicinity.

It may be assumed that their medieval heritage, continuity of administrative functions (state and church) and academic functions are conducive to strengthening their role in the urban network. Large industrial cities or cities of regional importance, such as Łódź, Bydgoszcz, Szczecin, Katowice and others in this conurbation still constitute strong links in this network, but their rank is declining year on year despite their other functions (academic, industrial, administrative). Cities located in eastern Poland (Lublin, Białystok, Rzeszów) are beginning to play an increasingly important role, which may be caused by the lack of other large cities in this part of Poland, which is a result of the detachment of Vilnius and Lviv from Poland and their incorporation into the USSR.

In conclusion, when undertaking scientific research on the contemporary urban network of Poland, many political, social and economic factors should be taken into account. These should be taken into account when making hypotheses, drawing conclusions and developing economic and geographical theories (Anderson, Ge, 2005).

\section{PRZYPISY}

\footnotetext{
${ }^{1}$ Historical names are given in brackets.

${ }^{2}$ For example, in the spatial arrangement of Kamieniec Podolski there are three markets: Polish, Armenian and Russian.

${ }^{3}$ The area of Polish state within its 1772 borders.
}

\section{BIBLIOGRAPHY}

Aldcroft, D.H. (2006). Europe's third world. Ashgate publishing. London: Routledge. https://doi.org/10.4324/9781315581156

Anderson, G., Ge, Y. (2005). The size distribution of Chinese cities. Regional Science and Urban Economics, 35 (6), 756-776. https:// doi.org/10.1016/j.regsciurbeco.2005.01.003

Antrop, M. (2004). Landscape change and the urbanization process in Europe. Landscape and Urban Planning, 67 (1-4), 9-26. https://doi.org/10.1016/S0169-2046(03)00026-4

Balcerowicz, L. (1994). Transition to the market economy: Poland, 1989-1993 in comparative perspective. Economic Policy, 9 (19), 71-97. https://doi.org/10.2307/1344601

Bretagnolle, A., Pumain, D. (2010). Simulating urban networks through multiscalar space-time dynamics (Europe and United States, $17^{\text {th }}-20^{\text {th }}$ Centuries). Urban Studies, 47 (13), 2819-2839. https://doi.org/10.1177/0042098010377366

Czaja, R. (2000). Miasta i ich posiadłości ziemskie w państwie zakonu krzyżackiego w Prusach. In: H. Nowak, R. Czaja (eds), Państwo zakonu krzyżackiego w Prusach. Podziaty administracyjne i kościelne w XIII-XVI wieku (pp. 45-65). Toruń: Wydawnictwo Naukowe Uniwersytetu Mikołaja Kopernika.

Długosz, Z. (2006). Migration of population in big Polish cities as compared to smaller cities and towns in the light ofselected parameters of the migration process. Bulletin of Geography, 6, 33-50. Retrieved from: http://www.bulletinofgeography.umk. pl/6_2006/03_dlugosz.pdf (14.01.2021).

Dziewoński, K. (1947). Przeobrażenia osadnictwa miejskiego w Polsce. Czasopismo Geograficzne, 18 (1-4), 202-231.

Frey, W.H., Zimmer, Z. (2001). Defining the city. In: R. Paddison (ed.), Handbook of urban studies (pp. 14-34). London, Thousand Oaks, New Delhi: Sage. https://doi.org/10.4135/9781848608375.n2

Grabowski, E. (1914). Skupienia miejskie w Królestwie Polskiem. Warszawa: Skład Główny w Księgarni E. Wende S-ka.

Guerin-Pace, F., Pumain, D. (1990). 150 Ans de croissance urbaine. Economie et Statistique, 230, 5-16. https://doi.org/10.3406/ estat.1990.5426

Hall, P.G., Pain, K. (eds) (2009). The polycentric metropolis: Learning from mega-city regions in Europe. The polycentric metropolis (earthscan). London: Routledge. https://doi.org/10.4324/9781849773911

Hartwell, C.A. (2018). The "hierarchy of institutions" reconsidered: Monetary policy and its effect on the rule of law in interwar Poland. Explorations in Economic History, 68, 37-70. https://doi. org/10.1016/j.eeh.2018.03.001

History of the Jagiellonian University (2019). Retrieved from: https:// en.uj.edu.pl/en_US/about-university/history (20.06.2019). 
Jażdżewska, I. (2001). Miejska sieć osadnicza i jej przemiany. In: S. Liszewski (ed.) Zarys monografii województwa łódzkiego (pp. 225-240). Łódź: Łódzkie Towarzystwo Naukowe.

Jażdżewska, I. (2006). Factors determining changes in urban settlement system in Poland in the $20^{\text {th }}$ century. Acta Facultatis Studiorum Humanitatis et Nature Universitatis Presoviensis. Folia Geographica, 10, 217-223.

Jażdżewska, I. (2008). Przemiany miejskiej sieci osadniczej w Polsce $w$ świetle metod matematycznych. Łódź: Wydawnictwo Uniwersytetu Łódzkiego.

Jażdżewski, K. (1957). Kształtowanie się wczesnośredniowiecznej kultury miejskiej w Polsce w świetle badań w latach 19451954. In: Pierwsza sesja archeologiczna IHKM PAN (pp. 319-347). Warszawa-Wrocław: Zakład im. Ossolińskich.

Jelonek, A. (1967). Niektóre problemy sieci miast na ziemiach Polski na początku XIX wieku. Zeszyty Naukowe Uniwersytetu Jagiellońskiego. Prace Geograficzne, 15, 95-112.

Kalinowski, W. (1986). Rozwój miast w Polsce. In: W. Zin (ed.), Zabytki urbanistyki i architektury w Polsce. Odbudowa i konserwacja. Vol. 1: Miasta historyczne. Warszawa: Ośrodek Dokumentacji Zabytków.

Kawashima, T., Korcelli, P. (eds) (1982). Human settlement systems: Spatial patterns and trends. Population and Development Review, 8 (4), 857-858. https://doi.org/10.2307/1972484

Koter, M., Kulesza, M. (1997). The historical background of the social and economic changes within small towns in Poland. In: K. Heffner, M. Ravbar (eds), Small European regions during transition period transformation of settlement systems (pp. 9-35). Opole: Instytut Śląski w Opolu.

Koter, M., Kulesza, M. (2001). Geographical and historical grounds of formation of borders of former and present-day Poland. In: M. Koter, K. Heffner (eds), Changing role of border areas and regional policies, region and regionalism (pp. 165-179). Łódź-Opole: Państwowy Instytut Nukowy, Instytut Śląski w Opolu. Retrieved from: http://geopol.geo.uni.lodz.pl/uploads/files/region-and-regionalism/R-and-R-05.pdf (15.01.2021).

Krzymowska-Kostrowicka, A. (1972). The impact of the railway on the development of Polish towns from 1860 to 1910. Geographia Polonica, 21, 53-61.

Krzysztofik, R. (2007). Lokacje miejskie na obszarze Polski: dokumentacja geograficzno-historyczna. Katowice: Wydawnictwo Uniwersytetu Śląskiego.

Krzysztofik, R., Szmytkie, R. (2005). Proces ksztaltowania się sieci miejskiej w Polsce w okresie od XIII do XX wieku. Czasopismo Geograficzne, 76 (4), 383-398.

Krzyżanowski, K., Kumaniecki, K. (1915). Statystyka Polska. Kraków: Skład Główny w Księgarni G. Gebethnera.

Kulesza, M., Kunka, T. (1994). Regions of Poland from historical perspectives - some selected remarks. Territories and boundaries from beginning of Polish statehood (966) to the partitions of Poland (1975). In: M. Koter (ed.), Inner divisions. Region and regionalism (pp. 97-102). Łódź-Opole: Univeristy of Lodz; Siliesian Institute in Opole.

Kwiatek-Sołtys, A. (2011). Small towns in Poland - barriers and factors of growth. Procedia - Social and Behavioral Sciences, 19, 363-370. https://doi.org/10.1016/j.sbspro.2011.05.143

Lijewski, T. (1977). Geografia Transportu. Warszawa: Państwowe Wydawnictwo Ekonomiczne.

Moomaw, R.L., Shatter, A.M. (1996). Urbanization and economic development: A bias toward large cities? Journal of Urban Economics, 40 (1), 13-37. https://doi.org/10.1006/juec.1996.0021

Murzyn-Kupisz, M., Gwosdz, K. (2011). The changing identity of the central european city: The case of Katowice. Journal of Historical Geography, 37 (1), 113-126. https://doi.org/10.1016/j. jhg.2010.04.001

Musiaka, Ł. (2015). Teutonic state order's cultural heritage in towns of Warmia-Masuria province in Poland. Geografické Informácie, 18 (2), 138-146. https://doi.org/10.17846/gi.2014.18.2.138-146

Rykiel, Z., Jażdżewska, I. (2002). The maturing of the Polish urban system. In: H.S. Geyer (ed.), International handbook of urban systems (pp. 271-294). Cheltenham, Northampton: Edward Elgar.

Samsonowicz, H. (1980). Tendencje rozwoju sieci miejskiej w Polsce późnośredniowiecznej. Kwartalnik Historii Kultury Materialnej, 28 (3), 341-348.

Samsonowicz, H. (2010). The rise and fall of the world of economy: Eastern Europe in $9^{\text {th }}-12^{\text {th }}$ centuries. Journal of World-Systems Research, 6 (2), 518-523. https://doi.org/10.5195/jwsr.2000.215

Śleszyński, P. (2013). Demographic changes in the functional urban areas in Poland, 2000-2010. Geographia Polonica, 86 (2), 169-170. https://doi.org/10.7163/gpol.2013.16

The Central Statistical Office. Retrieved from: https://stat.gov.pl/ (30.06.2018).

Wegener, M. (2013). Polycentric Europe: More efficient, more equitable and more sustainable? International Seminar on Welfare and Competitiveness in the European Polycentric Urban Structure, 7 June 2013, Florence.

Wolf, N. (2005). Path dependent border effects: The case of Poland's reunification (1918-1939). Explorations in Economic History, 42, 414-438. https://doi.org/10.1016/j.eeh.2004.10.002

Wolf, N. (2007). Endowments vs. market potential: What explains the relocation of industry after the Polish reunification in 1918? Explorations in Economic History, 44, 22-42. https://doi. org/10.1016/j.eeh.2005.08.003

Zuzańska-Zyśko, E. (2003). Population types of small towns in Silesian province. Bulletin of Geography, 2, 143-149.

Artykuł wpłynął: 16 czerwca 2020 Zaakceptowany do druku: 15 grudnia 2020 